\title{
ENVIRONMENTAL RISK FACTORS ASSOCIATED WITH BILIARY ATRESIA IN RIO GRANDE do SUL, BRAZIL
}

\author{
Larisse Longo ${ }^{1,2}$, Jéssica Tonin Ferrari ${ }^{1,2}$, Giovana Regina Weber Hoss ${ }^{1}$, \\ Leila Xavier Sinigaglia Fratta ${ }^{1}$, Sandra Maria Gonçalves Vieira ${ }^{2,3}$, \\ Themis Reverbel da Silveira ${ }^{1,2}$, Fernando Antônio de Abreu e Silva ${ }^{4}$, \\ Maria Teresa Vieira Sanseverino ${ }^{5,6}$, Jorge Luiz dos Santos ${ }^{1,7}$
}

\begin{abstract}
Biliary atresia (BA) seems to be a multifactorial disorder in which environmental factors interact with the patient's genetic constitution. This study aimed to analyze information concerning environmental risk factors associated with BA in southern Brazil. A case-control study with mothers of patients with BA and mothers of patients with cystic fibrosis (CF) was conducted. Inquiry included questions related to exposition to environmental risk factors during the periconceptional and gestational (second and third trimesters) periods. Mothers of BA patients had smoked during pregnancy more frequently in comparison with the mothers of CF patients, but no significant difference was found in a multivariate analysis. There was no between group difference in terms of seasonality, but the multivariate analysis showed a significant difference within the BA group between date of conception in winter compared to other seasons. In conclusion, smoking during pregnancy seemed to increase the risk of BA while date of conception in winter decreased it.
\end{abstract}

Keywords: Biliary atresia; environmental risk factor; etiology; seasonality; smoking

Biliary atresia (BA) is a disease that begins exclusively in infancy and consists in the complete obstruction of extrahepatic and intrahepatic bile ducts $^{1,2}$. Regardless of a timely surgical treatment, BA induces cirrhosis and cholangiopathy and constitutes the leading cause of pediatric liver transplantation ${ }^{3,4}$. The etiology of biliary obstruction and chronic cholangiopathy is not fully understood, and their association with genetic/chromosomal alterations, immune and immunogenetic abnormalities, environmental factors and maternal diseases, such as gestational diabetes, has been proposed ${ }^{1,5-7}$. An immune disorder induced by viral infection seems to be part of BA etiology ${ }^{8}$. Distinct variants of the disease, such as BA splenic malformation (BASM), isolated $B A$, cystic $B A$, and cytomegalovirus IgM-positive BA, suggest distinct patterns of acquisition ${ }^{3,7}$. BA seems to be a multifactorial disorder in which environmental factors interact with the patient's genetic constitution. Environmental risk factors associated with the development of BA have been seldom investigated ${ }^{5,9-12}$. In the present study, we collected and analyzed information concerning family history and environmental risk factors in the gestational and periconceptional periods associated with the occurrence of BA in the state of Rio Grande do Sul, southern Brazil, aiming to elucidate the etiology of this disease.

\section{METHODS}

This was a case-control study in which the evaluated sample included mothers of patients with the isolated form of BA. The investigation was conducted during the first weeks after birth or at different points during outpatient follow-up. Mothers of infants, children and adolescents (up to 18 years old)
Clin Biomed Res. 2017;37(2):87-90

1 Experimental Laboratory of Hepatology and Gastroenterology, Hospital de Clínicas de Porto Alegre (HCPA). Porto Alegre, RS, Brazil.

2 Graduate Program in Gastroenterology and Hepatology, Universidade Federal do Rio Grande do Sul (UFRGS). Porto Alegre, RS, Brazil.

3 Pediatric Hepatology Unit, Hospital de Clínicas de Porto Alegre (HCPA). Porto Alegre, RS, Brazil.

4 Pediatric Pneumology Unit, Hospital de Clínicas de Porto Alegre (HCPA). Porto Alegre, RS, Brazil.

5 Medical Genetics Service, Hospital de Clínicas de Porto Alegre (HCPA). Porto Alegre, RS, Brazil.

6 School of Medicine, Pontifícia Universidade Católica do Rio Grande do Sul (PUCRS). Porto Alegre, RS, Brazil.

7 Faculty of Health Sciences, Health Sciences Research Centre, University of Beira Interior (CICS-UBI). Covilhã, Portugal.

Corresponding author: Larisse Longo larisselongo@hotmail.com Experimental Laboratory of Hepatology and Gastroenterology, Hospital de Clínicas de Porto Alegre (HCPA) Rua Ramiro Barcelos, 2350. 90035-903, Porto Alegre, RS, Brazil. 
treated by the same clinical and surgical teams in the Pediatric Hepatology Unit of the Service of Pediatrics of Hospital de Clínicas de Porto Alegre (HCPA) were included in the case group. Mothers of patients with cystic fibrosis (CF) who joined the study during inpatient or outpatient care of their children at the Pediatric Pneumology Unit of HCPA were included in the control group. CF was chosen as control because it has a well-defined genetic basis and the age of diagnosis is similar to BA. Data collection was performed from 2009 to 2015 by a single team of interviewers. Mothers who agreed to participate had adequate memory skills and lived in Rio Grande do Sul during pregnancy and at birth. They were informed about objectives and methods of the study, signed an informed consent form, and then answered a standard questionnaire about environmental risk factors of BA during periconceptional and gestational (second and third trimesters) periods. Investigated risk factors comprised 45 items, including consumption of cigarettes, alcohol, illicit drugs, teas, and erva-mate
(Ilex paraguaiensis St. Hill), and use of medications, condoms and skin creams. Additional topics were parents' age, pregnancy planning, season at conception and at birth, and diagnosis of infections. To control a possible bias related to mothers' long-term memory, children of both groups were matched by age at questionnaire application. The study was approved by the Research Ethics Committee of HCPA.

\section{STATISTICS}

Data were described as ranges, means \pm standard deviations, and medians (25th-75th percentiles). Student's $t$-test and Mann-Whitney test were used for quantitative variables, and chi-square test and Fisher's exact test were used for categorical variables. Confounding factors were controlled by multiple regression analysis, when variables had a $P$-value of $<0.10$ in a bivariate analysis. A $P$-value of $\leq 0.05$ was considered significant.

Table 1: Characterization of samples according to studied variables.

\begin{tabular}{|c|c|c|c|}
\hline Variables* & $B A(n=27)$ & CF (n= 27) & $P$ \\
\hline Age (mother) & $29(21-33)$ & $23(20-31)$ & 0.307 \\
\hline Age (father) & $30(25.5-33)$ & $29(25-34)$ & 0.646 \\
\hline Smoking habit (pregestational) & $7(25.9)$ & $3(11.1)$ & 0.293 \\
\hline Smoking habit (during pregnancy) & $7(25.9)$ & $1(3.7)$ & 0.050 \\
\hline Living with smokers & $16(59.3)$ & $15(55.6)$ & 1.000 \\
\hline Alcohol (during pregnancy) & $6(22.2)$ & $1(3.7)$ & 0.100 \\
\hline Illicit drugs (pregestational) & $2(8.0)$ & 0 & 0.226 \\
\hline Illicit drugs (during pregnancy) & $2(8.0)$ & 0 & 0.226 \\
\hline Teas & $8(29.6)$ & $4(14.8)$ & 0.327 \\
\hline Erva-mate ${ }^{* *}$ & $19(70.4)$ & $21(77.8)$ & 0.757 \\
\hline Exposition to condoms (during pregnancy) & $3(11.1)$ & $3(11.1)$ & 1.000 \\
\hline Vitamins & $6(22.2)$ & $9(33.3)$ & 0.540 \\
\hline Folic acid & $11(40.7)$ & $16(59.3)$ & 0.280 \\
\hline Iron & $11(42.3)$ & $13(48.1)$ & 0.785 \\
\hline Cream (anti-acne, during pregnancy) & $1(5.6)$ & $2(7.4)$ & 1.000 \\
\hline Cream (anti-stretch marks, during pregnancy) & $10(55.6)$ & $11(40.7)$ & 0.374 \\
\hline Pregnancy planning & $17(63.0)$ & $13(48.1)$ & 0.412 \\
\hline Season at conception & & & 0.086 \\
\hline Summer & $14(51.9)$ & $8(29.6)$ & \\
\hline Autumn & $6(22.2)$ & $4(14.8)$ & \\
\hline Winter & $3(11.1)$ & $11(40.7)$ & \\
\hline Spring & $4(14.8)$ & $4(14.8)$ & \\
\hline Season at birth & & & 0.590 \\
\hline Summer & $8(29.6)$ & $12(44.4)$ & \\
\hline Autumn & $6(22.2)$ & $4(14.8)$ & \\
\hline Winter & $4(14.8)$ & $5(18.5)$ & \\
\hline Spring & $9(33.3)$ & $6(22.2)$ & \\
\hline
\end{tabular}

*Variables are described as mean \pm standard deviation, median (25th-75th percentiles), or frequency (\%); ${ }^{* *} / l e x$ paraguaiensis St. Hill. Abbreviations: BA, biliary atresia; CF, cystic fibrosis. 
Table 2: Multiple logistic regression to evaluate independent factors associated with biliary atresia.

\begin{tabular}{lcc}
\hline \multicolumn{1}{c}{ Variables } & OR $(95 \% \mathrm{Cl})$ & $P$ \\
\hline Smoking habit (during pregnancy) & $8.48(0.89-81.0)$ & 0.063 \\
Season at conception (winter) & $0.19(0.04-0.85)$ & 0.030 \\
\hline
\end{tabular}

These variables were the only ones with $P<0.10$ in a bivariate analysis.

\section{RESULTS}

Each group (BA and CF) consisted of 27 mothers. Fifteen mother of BA patients (55.6\%) were female, and at the time of inquiry, they had a median age of 5 (2-9) years. Among mothers of CF patients, 17 (63\%) were female, and their median age was 4 (2-9) years. There were no significant differences in relation to sex $(P=0.782)$ nor age at inquiry $(P=0.986)$.

Mothers of BA patients had been smokers during pregnancy more frequently than mothers of CF patients $(P=0.050$, table 1$)$, but the multivariate analysis (table 2) showed no significant difference $(P=0.063$; odds ratio, $\mathrm{OR}=8.48 ; 95 \% \mathrm{Cl}$ : 0.89-81.0). The following variables showed significant associations with BA: parents' age; pregnancy of non-smokers living with smokers or with a pregestational smoking habit; consumption of alcohol or illicit drugs before, during, or after pregnancy; consumption of erva-mate or teas; use of medications, skin creams, or condoms during an unsuspected pregnancy (table 1).

There was no between-group difference in relation to seasonality at conception and at birth $(P=0.086$ and $P=0.591$, respectively) (table 1 ). However, considering specifically the BA group, there was a significant difference $(P=0.030)$ in the multivariate analysis between date of conception in winter compared to other seasons (OR $=0.19,95 \% \mathrm{Cl}: 0.04-0.85)$ (table 2), demonstrating a lower risk of developing BA when conception occurs in winter. There was no significant association between the presence of BA and infections during the time periods of interest. Moreover, mothers of BA and CF patients did not report any intestinal infection during the second and third trimesters of gestation.

\section{DISCUSSION}

In terms of etiology, biliary atresia seems to be a heterogeneous condition in which environmental factors can act both in the early intrauterine period (embryonic form) and in the perinatal period (isolated form $)^{13-16}$.

This study showed that the conception of a patient with BA was $84 \%$ less likely if this condition was diagnosed in winter, suggesting a seasonal influence on BA etiology, although season at birth was not associated with the occurrence of BA. Seasonality suggests that environmental factors can trigger $\mathrm{BA}$, but conflicting results have been described on this topic ${ }^{9-11,17-19}$. In Texas, a higher number of BA patients were born during summer and spring in the countryside, suggesting that the noxious agent could be an agricultural toxin ${ }^{17}$. In New York, babies born in spring were at a higher risk of suffering from $\mathrm{BA}^{18}$. The NS et al. observed that conception during spring was more associated with the occurrence of BA than conception during winter ${ }^{9}$. Other groups from different countries have found no association of BA with seasonality ${ }^{5,10-12,19}$. Different investigation methods, samples sizes, and environmental or weather conditions in different regions may explain these conflicting results.

In the present study, mothers of BA patients were smokers during pregnancy more frequently than controls, but there was only a tendency of difference in the multivariate analysis. Fischler et al. obtained similar results for pregnant women consuming more than 10 cigarettes $/$ day $^{11}$. Another study did not find association between active or passive smoking habit during pregnancy and $\mathrm{BA}^{9}$. The putative association of maternal smoking and $B A$ is interesting, since the livers of BA patients have a molecular profile suggestive of hypoxia-ischemia possibly attributable to vascular disorders ${ }^{7}$.

The present study did not find any relation between the occurrence of BA and the other investigated variables. The absence of relation between $B A$ and genitourinary or gastrointestinal infections during periconceptional and gestational periods observed in this study is consistent with the findings of The NS et al., but they observed an association between respiratory infections during the periconceptional period and the occurrence of $\mathrm{BA}^{9}$.

This is the first report from Brazil of environmental risk factors for BA. The low incidence of this disease made our work challenging, but the high morbidity/ mortality rate associated with BA makes it crucial to further investigate infectious and non-infectious risk factors associated with its etiology. In conclusion, this study showed that date of conception during winter decreased the risk of $\mathrm{BA}$, while smoking during pregnancy seemed to increase it.

\section{Acknowledgements}

We thank the Pediatric Hepatology Unit and the Pediatric Pneumology Unit of the Hospital de Clínicas de Porto Alegre. 


\section{Conflicts of interest}

The authors declare no conflicts of interest.

\section{REFERENCES}

1. Santos JL, Carvalho E, Bezerra JA. Advances in biliary atresia: from patient care to research. Braz J Med Biol Res. 2010;43(6):5227. PMid:20464347. http:// dx.doi.org/10.1590/S0100879X2010007500035.

2. Chardot C. Biliary atresia. Orphanet J Rare Dis. 2006;1(1):28. PMid:16872500. http://dx.doi. org/10.1186/1750-1172-1-28.

3. Hartley JL, Davenport M, Kelly DA. Biliary atresia. Lancet. 2009;374(9702):1704-13. PMid:19914515. http://dx.doi. org/10.1016/S0140-6736(09)60946-6.

4. Carvalho E, Santos JL, Silveira TR, Kieling CO, Silva LR, Porta $G$, et al. Biliary atresia: the Brazilian experience. J Pediatr. 2010;86(6):4739. PMid:21140036.

5. Wada H, Muraji T, Yokoi A, Okamoto T, Sato S, Takamizawa $\mathrm{S}$, et al. Insignificant seasonal and geographical variation in incidence of biliary atresia in Japan: a regional survey of over 20 years. J Pediatr Surg. 2007;42(12):20902. PMid:18082714. http://dx.doi. org/10.1016/j.jpedsurg.2007.08.035.

6. Schwarz KB, Haber BH, Rosenthal P, Mack CL, Moore J, Bove K, et al. Extrahepatic anomalies in infants with biliary atresia: results of a large prospective North American multicenter study. Hepatology. 2013;58(5):1724-31. PMid:23703680. http://dx.doi.org/10.1002/hep.26512.

7. Fratta LX, Hoss GR, Longo L, Uribe-Cruz C, da Silveira TR, Vieira SM, et al. Hypoxic-ischemic gene expression profile in the isolated variant of biliary atresia.
$J$ Hepatobiliary Pancreat Sci. 2015;22(12):846-54. PMid:26510548. http://dx.doi.org/10.1002/jhbp.297.

8. Bessho K, Mourya R, Shivakumar P, Walters S, Magee JC, Rao M, et al. Gene expression signature for biliary atresia and a role for interleukin-8 in pathogenesis of experimental disease. Hepatology. 2014;60(1):21123. PMid:24493287. http://dx.doi. org/10.1002/hep.27045.

9. The NS, Honein MA, Caton AR, Moore CA, Siega-Riz AM, Druschel CM. Risk factors for isolated biliary atresia, National Birth Defects Prevention Study, 1997-2002. Am J Med Genet A. 2007;143A(19):227484. PMid:17726689. http://dx.doi. org/10.1002/ajmg.a.31926.

10. Chardot C, Carton M, Spire-Bendelac N, Pommelet CL, Golmard J-L, Auvert B. Epidemiology of biliary atresia in France: a national study 1986-96. J Hepatol. 1999;31(6):100613. PMid:10604573. http://dx.doi. org/10.1016/S0168-8278(99)80312-2.

11. Fischler B, Haglund B, Hjern A. A population-based study on the incidence and possible pre- and perinatal etiologic risk factors of biliary atresia. J Pediatr. 2002;141(2):21722. PMid:12183717. http://dx.doi. org/10.1067/mpd.2002.126001.

12. Livesey E, Borja MC, Sharif K, Alizai N, McClean P, Kelly D, et al. Epidemiology of biliary atresia in England and Wales (1999-2006). Arch Dis Child Fetal Neonatal Ed. 2009;94(6):F451-5. PMid:19457876. http://dx.doi.org/10.1136/ adc.2009.159780.

13. Mack CL, Feldman AG, Sokol RJ. Clues to the etiology of bile duct injury in biliary atresia. Semin Liver Dis. 2012;32(4):307-16. PMid:23397531. http://dx.doi. org/10.1055/s-0032-1329899.

14. Bessho K, Bezerra JA. Biliary atresia: will blocking inflammation tame the disease? Annu Rev Med. 2011;62(1):171-85. PMid:21226614. http://dx.doi.org/10.1146/annurevmed-042909-093734.

15. Sokol RJ, Mack C, Narkewicz MR, Karrer FM. Pathogenesis and outcome of biliary atresia: current concepts. $J$ Pediatr Gastroenterol Nutr. 2003;37(1):4-21. PMid:12827000. http://dx.doi.org/10.1097/00005176200307000-00003.

16. Carvalho E, Ivantes CA, Bezerra JA. Extrahepatic biliary atresia: current concepts and future directions. J Pediatr. 2007;83(2):105-20. PMid:17426869.

17. Strickland AD, Shannon K. Studies in the etiology of extrahepatic biliary atresia: time-space clustering. J Pediatr. 1982;100(5):749-53. PMid:7069535. http://dx.doi. org/10.1016/S0022-3476(82)80576-3.

18. Caton AR, Druschel CM, McNutt LA. The epidemiology of extrahepatic biliary atresia in New York State, 1983-98. Paediatr Perinat Epidemiol. 2004;18(2):97-105. PMid:14996248. http://dx.doi.org/10.1111/j.13653016.2003.00536.x.

19. Houwen RH, Kerremans II, van Steensel-Moll HA, van Romunde LK, Bijleveld CM, Schweizer P. Timespace distribution of extrahepatic biliary atresia in The Netherlands and West Germany. Z Kinderchir. 1988;43(2):68-71. PMid:3388982.

Received: Mar 01, 2017 Accepted: May 17, 2017 